p. 230

体有学

\section{Jahn における体市（Turnen）の结念について}

東京大学山本 微 郎

従来我国では，“Turnen”を(ドイッ) 体操，体青と 訳し，器械運動を中心としたひとつの体系と考えてを た。この用語の概念は，Jahn が 1811 年に用いはじめ てから，いろいろな变退をたどつている．本研究は， Jahn に扑ける Turnenの概念の成立邀程考察し，そ の意味を問おらとするるのである。

1810 年, Jahn は “Das dentsche Volkstum”を出 し，彼の Volkstum の思想を明らかにした。その中の Volkserziehung の章のところで，そのひとつの手段と して Leibesübungen が挙げられえいる.その内容は体 系化されたものではなかつた. Guts Muths 周边の体育

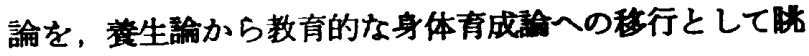
めた場合，この Volkstum における Leibesübungen は養生論的性格が失なわれ，身体育成論の面です，沉 主義的人間形成の手段から，Volkstumlich な人間形成 の手段へと変つている. 教育の中のひとつの領城として Leibeserziehung を考光，その中のひとつの方法とし て gymnastik を位置つけた Guts Muthsの場合と異な り, Jahn は Leibesübungen $を$ Volkserziehung $k$ 直 接結びつけている.これは Leibesübungen が，青少年 の教育活野である Turnen 活娌の手既となるべき下地 を作つたことになる。

Jahn は1810年から，当時学校行事的に抗こなわれ， 学生達に習慣化していた，学校外の室地や草原でおこな われた身体活動に積函的に加したＪahn はこの活 動に Turnen (Turnkunst) という新らしい用蓓を与え た。それは当時の国民的な感堂と，Jahn の母国語思想 によるるのであつた。 とすかく Jahn は、このよ5な 活動の中に，国民が真の国民下なるため下不可欠なVolkstum の思想を育てる力を感したのであろう．このよ らにして，身体活動の青少年教育的意美を櫂めた Jahn は，多くの協力者に恵まれながらその発展のために尽力 し，ひとつの体系を作りあげた。これが怆なられ Turnkunst なのである. 曼初は学生を中心炕しておこ なわれたこの活動む，次第に一般の人々る加するよう になり，伝脚的な Verein 活動の根源人と発展してい くのである.

Jahn の Turnkunst は，Volkstum 思想のひとつの 具体的な実践活動であつて，その意味では，Turnkunst は Volkserziehung と同军的なるのと考えてよいであ

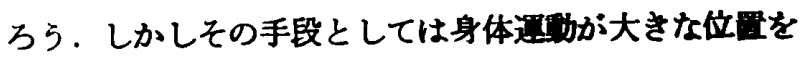
占めていた。 たからといつて Turnkunst は Leibesti- bungen の単なる総称であないのである. Turnkunst は，青少年の間任 gemeinde の精神を形成しようとす ろるので, Turnübungen, Turnspiele 等の 身体運動の はが，楽しく会話をかわしたり，皆で歌を唄つたり， 時には時局の問题について話し合つたりする機会が与之 られた．更に加者の数や年令等の関係から Turnen

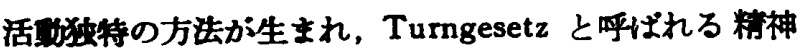
网要的なるのが示されたり，有名な 4 F (Frisch, frei, frohlich, fromm) を Turnen の基本的なるのとしたり して，Turnen 独特の性格が形成されたのである. 即ち Turnkunst, Turnwesen と呼ばれるものは, Leibesübungen を中心的な方法とした，ひとつの青少年教育 体系の全体を意味するるのである。

要するに Turnkunst は Guts Muths 等に見られるよ らな，主として身体遇的を通して肉体的资貫の発育発達 を考える体有詥とくらぺて，身体運動を利用して gemeinde の精神の発速を考光，政治的人間の教育，Staatsburger の教育を目楼とする面の方が強かつた。ここ でおこなわれた身体画加は，若干独自の器具の刑入はあ つたにせよ，Guts Muths の Gymnastik, Spiel と領域 的には硚んど变つていない，しかし，これは Turnenの

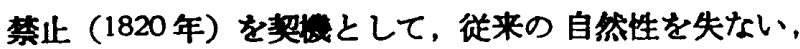
Spietz-maul 方式に代表されるようなるのへと変化し， 今世杞に入つて Hébert や, Gaulhofer-Streicher 等に 上つて再度の改革が為されるようになる。

\section{(主需文涞)}

1) O.C.C. Hopffner (F.L. Jahn): Über die Beforderung des Patriotismus im Preutzischen Reiche, 1800.

2) F.L. Jahn: Bereicherung des Hochdeutschen Sprachschatzes, 1806.

3) F.L. Jahn: Das deutsche Volkstum, 1810.

4) F.L. Jahn u. E. Eiselen: Die deutsche Turnkunst, 1816.

5) K. Wildt: F.L. Jahn und das deutsche Turnen, 1931.

6) E. Neuendorff : Geschichte der neueren deutschen Leibesubung vom 18, Jahrhundert bis zur Gegenwart, 1932.

7) E. mehl : Der Begriff "Turnen", 1953.

8) V.E. milde: Urteil uber Jahns "Deutsche Turnkunst", 1817 (in "Leibesübungen-Leibeserziehung", 1963, H. 5). 